\title{
EXPERIMENTAL AND MODELING STUDIES OF HYDROSTATIC SYSTEMS WITH THE COUNTERBALANCE VALVES WHICH ARE USED IN HYDRAULIC LIFTING SYSTEMS WITH PASSIVE AND ACTIVE LOAD
}

\section{EKSPERYMENTALNE I MODELOWE BADANIA UKŁADU HYDRAULICZNEGO Z ZAWORAMI HAMUJĄCYMI TYPU COUNTERBALANCE STOSOWANYMI W UKŁADACH DŹWIGOWYCH Z OBCIĄŻENIEM BIERNYM I CZYNNYM*}

\begin{abstract}
The article describes the structure and principle of the brake valve type counterbalance and the impact of its setup on the operatnig safety of hydrostatic systems with variable load, and in particular the problem of vibration and instability of operation of such systems after stop and restart with the active load. Mathematical and physical models of the valve and hydrostatic system with variable load have been developed. The models have been verified on the test bench, on which it is possible to the formation of arbitrary diagrams and extortion. The static and dynamic charasteristics of the valve and the key operating parametres of the hydrostatic system that affect its useful properties have been shown. The simulation studies, which identify critical design parametres of the valve, that are crucial to the behaviour of the valve, and thus, hydrostatic system, has been carried out.
\end{abstract}

Keywords: operating safety of machines, hydrostatic systems, braking valves, counterbalance valve, platforms, cranes.

\begin{abstract}
Artykut opisuje budowę oraz zasadę działania zaworu hamującego typu counterbalance oraz wpływ jego nastaw na bezpieczeństwo pracy układów hydrostatycznych przy zmieniającym się obciążeniu, a w szczególności problem drgań i niestabilności pracy takiego układu hydrostatycznego po zatrzymaniu i ponownym uruchomieniu po przejściu z obciażenia biernego na czynne. Opracowane zostały modele matematyczne i fizyczne zaworu oraz układu hydrostatycznego ze zmiennym obciażeniem, które zweryfikowano na stanowisku badawczym, na którym możliwe jest kształtowanie dowolnych przebiegów i wymuszeń. Zamieszczone zostały charakterystyki statyczne i dynamiczne zaworu oraz przebiegi kluczowych parametrów pracy układu hydrostatycznego, które maja wplyw na jego właściwości użytkowe. Przeprowadzone badania symulacyjne identyfikują krytyczne parametry konstrukcyjne zaworu, które mają kluczowe znaczenie na zachowanie się zaworu, a co za tym idzie, układu hydrostatycznego. Stowa kluczowe: bezpieczeństwo obsługi maszyn, uktady hydrostatyczne, zawór hamujacy, counterbalance, dźwigi koszowe, żurawie.
\end{abstract}

Slowa kluczowe: bezpieczeństwo obstugi maszyn, układy hydrostatyczne, zawór hamujący, counterbalance, dźwigi koszowe, żurawie.

\section{Introduction}

The hydrostatic systems with variable load, as well as the value and the nature of action, are used in many indrustries. There may be different hydraulic solutions using the appropriate braking valves (Fig. 1.1), whose tasks include brake piston rod loaded with cargo, where it is necessary to receive power during lowering, including excavators, wheel loaders or cranes. With the correct setting, the valve also controls the movement of the piston rod with the variable load throught the work cycle (for example - eject and/or return movement of the piston rod). Thus it provides a stable work wih active force (the force vector and velocity vector are in the same sense) and passive force (the force vector and velocity vector have opposite sense). Examples of applications with braking valves are: scissor lifts, hydraulic cranes or containers lifting systems in garbage trucks. Importantly, all of the hydraulic machines operating in the EU, working as a cranes or lift loads above 1 tonne, must be secured before breaking wires. This protection is achieved thanks to braking valves. The main European document that describes the essential safety requirements for currently marketed or put into using of machinery in the European Union is di- rective 2006/42/EC. In the field of hydraulic systems and components of machines, the norm harmonized with the Directive 2006/42/EC is accordingly BS EN ISO 4413 (Drives and hydraulic control - General rules and safety requirements for systems and their components). One of the most important feature of the norm is to realize manufacturers and service staff of machines, etc., what are the dangers of using a hydraulic system. To the most notable include, among others, these about the typically mechanical origin, for example, associated with moving actuators, inadequate material strength of the components or accumulation of energy. Another important group are those resulting from the failure of the machine control system, for example, manifesting unusual reactions machines and systems as a result of loss of power supply or unexpected extrudes of machine parts or substances. It should be noted that the safety of these installations often depends on the reliability of the control circuit. For this purpose, in their construction it is necessary to take into account the requirements of the PN-EN ISO 13849-1 - Parts of control systems security. Research on this valve have been undertaken before those provisions came into effect and according to the data sheet of one of manufacturer [8] which gave only a small, incomplete and general information - the flow

(*) Tekst artykułu w polskiej wersji językowej dostępny w elektronicznym wydaniu kwartalnika na stronie www.ein.org.pl 


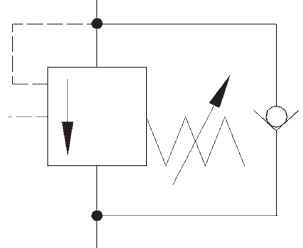

Fig. 1.1. Braking valve type counterbalance-graphic symbol

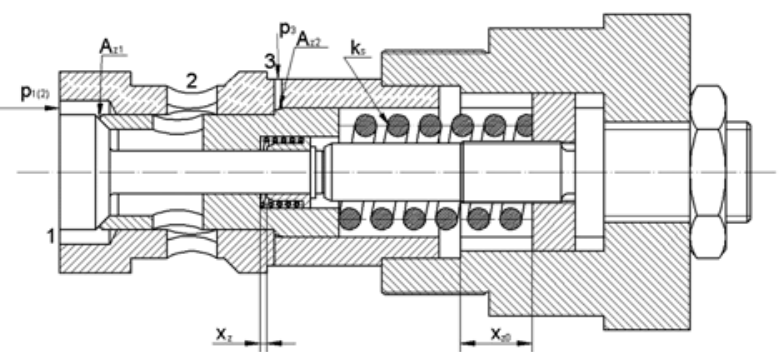

Fig. 1.2. Braking valve type UZPHD10 (Ponar Wadowice) - constructional scheme

Table 1. Braking valve type UZPHD10 (Ponar Wadowice) - work parametres

\begin{tabular}{|l|l||}
\hline Working fluid & Mineral oil \\
\hline Nominal viscosity liquids & $37 \mathrm{~mm} 2 / \mathrm{s} \mathrm{in} \mathrm{temp.} 328 \mathrm{~K}\left(55^{\circ} \mathrm{C}\right)$ \\
\hline Liquid viscosity range & 2,8 to $328 \mathrm{~mm} 2 / \mathrm{s}$ \\
\hline $\begin{array}{l}\text { The optimum working tempera- } \\
\text { ture (fluid in a tank) }\end{array}$ & 313 to $328\left(40\right.$ to $\left.55^{\circ} \mathrm{C}\right)$ \\
\hline Temperature range & 243 to $343\left(-30\right.$ to $\left.70^{\circ} \mathrm{C}\right)$ \\
\hline Required fluid filtration & $16 \mu \mathrm{m}$ \\
\hline Recommended fluid filtration & $10 \mu \mathrm{m}$ \\
\hline Max. pressure of work & $30 \mathrm{MPa}$ \\
\hline Max. flow & $120 \mathrm{dm} 3 / \mathrm{min}$ \\
\hline Checkvalve opening pressure & $0.2 \mathrm{MPa}$ \\
\hline Ratio of the opening valve & 4.5 \\
\hline Mass & $0.45 \mathrm{~kg}$ \\
\hline
\end{tabular}
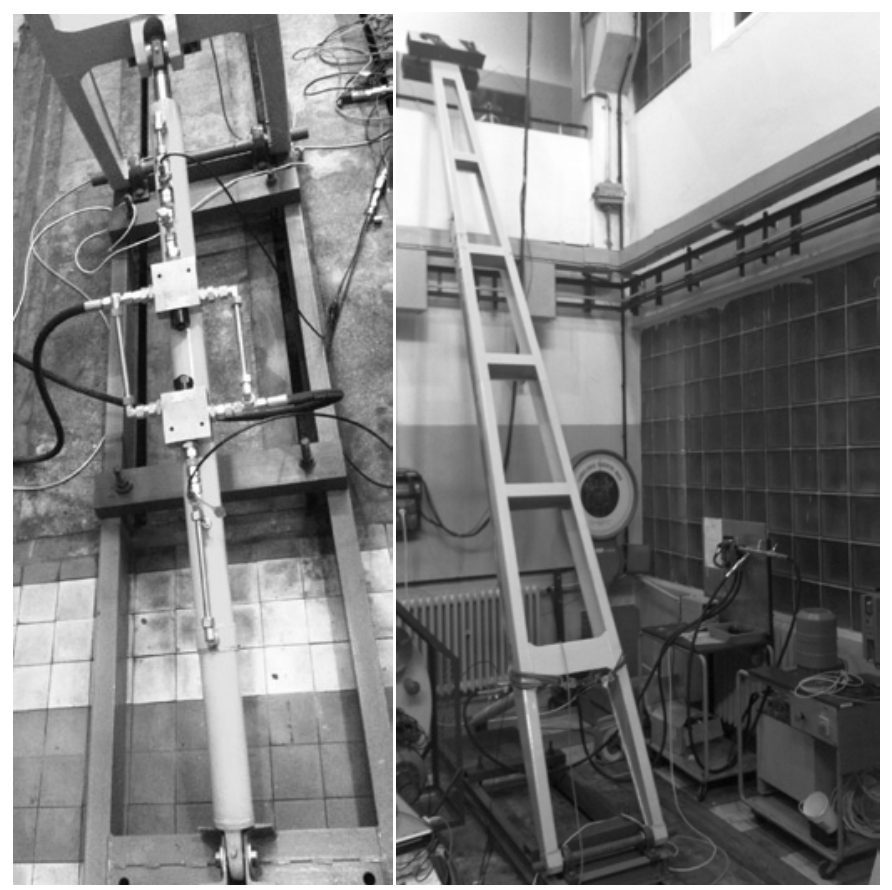

Fig. 2. The test stand for hydrostatic systems with variable load characteristics and the flow resistance characteristics through checkvalve (flow through the valve in the opposite direction without the need to throttle). Table 1 presents work parametres for this specific braking valve from Ponar Wadowice. Therefore it seems appropriate to conduct a more thorough analysis of the brake valve's behavior at its various settings and the possibilities of control, which is included in this article.

During operation of these systems there may appear vibrations, uncontrolled movements of the piston rod, as well as the power losses during the lowering of loads (active load) - the issues discussed subsequently various examples of machines in the literature $[1,2,3,4,6$, $7,9,10,14,17]$. In the papers $[1,3,11]$, there are also negative energetic aspects, which are inherent to the inappropriate use of valves, for example, very high pressure in hydraulic systems and heating of the oil, which means there is the outflow of energy as heat. However, specialist literature does not discuss the problem that may arise in such systems, namely a negative pressure in one of the chambers of the actuator and the cavitation phenomenon which are dangerous and may lead to the destruction of the system. The worst situation is when machine works with an active force, for example, lowering the load. Insufficient pump capacity and excessive speed of the piston rod can reduce the pressure in the supply line actuator, which can be a cause of pressure below atmospheric. The adverse situation may also occur in case of a power failure, in the moment when the system is loaded activly. During the restart difficulties with smooth and controlled start-up and operation of the actuator are observed, and thus the entire mechanism, especially at large masses of cargo and supporting structures. It is important, therefore, that the system ensured the safety work of the entire device, including safe control and operation.

Because of the need for accuracy of hydraulic actuators, the research on the control systems of movement of the piston rod, the braking and start-up, in varying operating conditions is needed. The interest in these issues on the part of the engineering industry and the transport was a direct reason to work on the construction of position to study the behavior of systems with variable load for different hydraulic solutions. The envolved system is designed for solutions with a pump fixed or variable capacity unit with double-acting actuator, as part of an executive with the ability to change its load, as well as the value and the nature of action. In the Division of Working Machines, Drives and Control at the Technical University of Lodz laboratory stand was built (Fig. 2) for testing hydraulic systems with variable load cylinder, equipped with two identical counterbalance valves.

The entire system is described in the literature [13], simulation test system were included in the article [12], and model verification position was included in the author $\mathrm{PhD}$ thesis. The counterbalance valve model was verified by experimental investigations of the system and thus helped further simulation of the valve itself. The graphs below show the diagrams of variables, during the piston rod extends (Fig. 3.1 - Fig. 3.3) and during its return to the cylinder of the hydraulic actuator (Fig. 3.4 - Fig. 3.6) at variable load, constant capacity hydraulic pump and fixed valve settings. Spring pre-tension in the valves is different for the different directions, due to the different surfaces (side of the piston or the piston rod cross-sectional area). Therefore, remember to set the valves for the various directions of the actuator, so as not to expose themselves for dangerous situations. The results confirm the good quality of the model. Average deviations are as follows:

- eject of the piston rod:

$\delta p_{2}=4.95 \%, \delta p_{3},=11.29 \%$ - deviations of the control pressure $\mathrm{p}_{2}$ i $\mathrm{p}_{3}$,

$\delta L s i l=2.45 \%$ - deviations of the whole lenght of the actuator $\mathrm{L}_{\mathrm{sil}}$,

$\delta v=2.62 \%-$ deviations of the piston rod velocity $\mathrm{v}_{\mathrm{T}}$, 


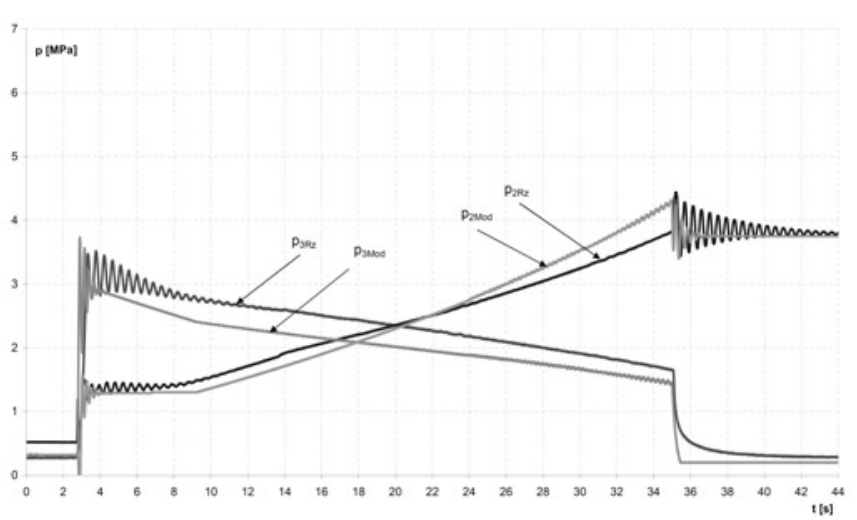

Fig. 3.1. Experimental and model waveforms of control pressures $p_{2}$ and $p_{3}$ of the braking valves during the eject of piston rod

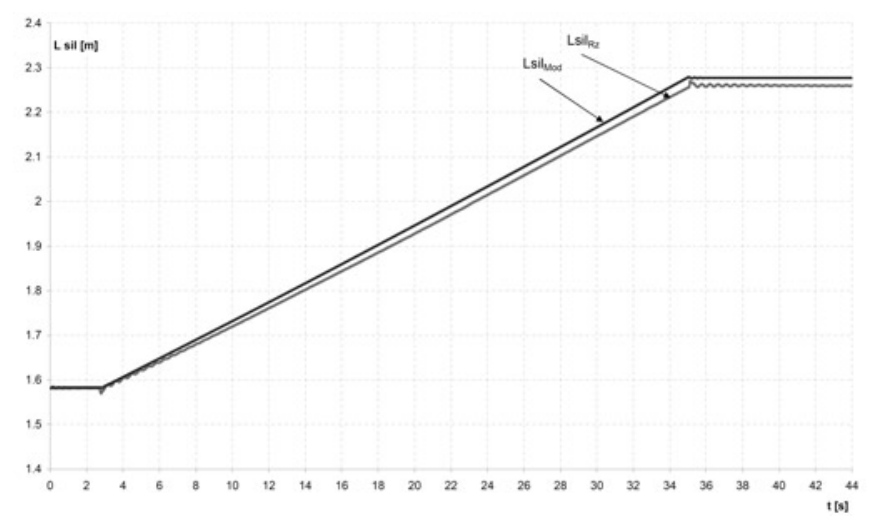

Fig. 3.2. Experimental and model waveforms of whole lenght of actuator $L_{\text {sil }}$ during the eject of piston rod.

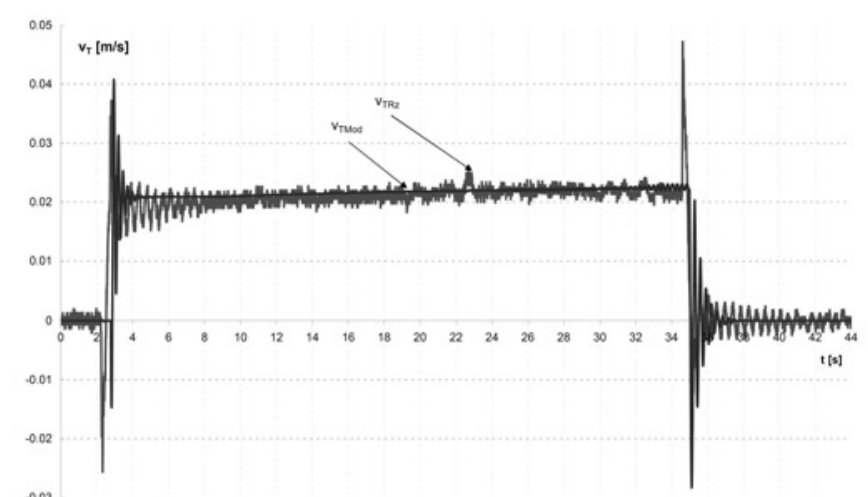

Fig. 3.3. Experimental and model waveforms of speed of actuator $v_{T}$ during the eject of piston rod

- return movement of the piston rod:

$\delta p_{1}=5.98 \%, \delta p_{3},=13.40 \%$ - deviations of the control pressure $\mathrm{p}_{2}$ i $\mathrm{p}_{3}$,

$\delta L s i l=2.45 \%-$ deviations of the whole lenght of the actuator $\mathrm{L}_{\text {sil, }}$

$\delta v=1.12 \%-$ deviations of the piston rod velocity $\mathrm{v}_{\mathrm{T}}$,

\section{Analysis of the braking valve type counterbalance}

The counterbalance valve is controlled by two independent pressures. Their weighted sum gives a signal to open the valve. Due to the construction of the valve (Fig. 1.2) pressure $\mathrm{p}_{3}$ gives much larger amplification than pressure $\mathrm{p}_{1}$. The valve can be opereted in both directions of flow movement, as the braking valve $(1 \rightarrow 2)$ or check valve $(2 \rightarrow 1)$.

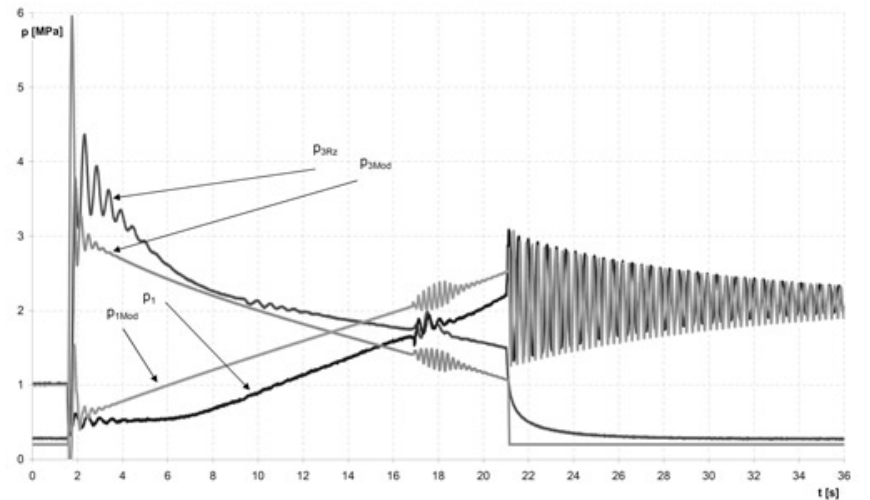

Fig. 3.4. Experimental and model diagrams of control pressures $p_{1}$ and $p_{3}$ of the braking valves during the return movement of piston rod

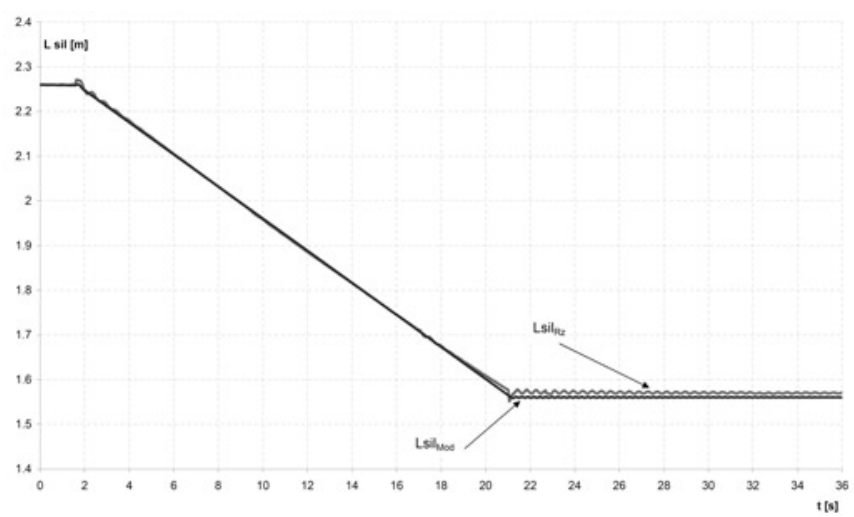

Fig. 3.5. Experimental and model diagramss of whole lenght of actuator $L_{\text {sil }}$ during the return movement of piston rod

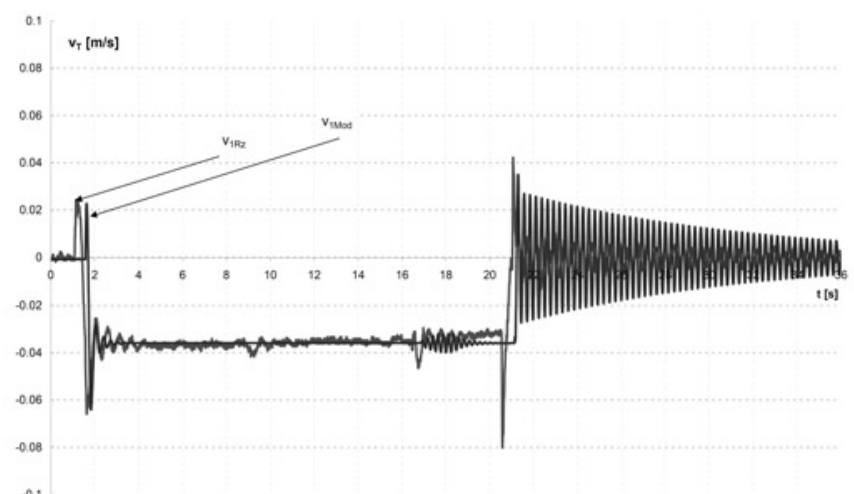

Fig. 3.6. Experimental and model diagramss of speed of actuator $v_{T}$ during the return movement of piston rod

Flow from channel 1 to channel 2 is structurally restricted by the plunger which is based on the spring. As long as the pressure $p_{1}$ and $\mathrm{p}_{3}$, acting on two sections $\mathrm{A}_{\mathrm{z} 1}$ and $\mathrm{A}_{\mathrm{z} 2}$, not overcome the force of the spring, the piston does not move and fluid cannot flow. In addition, the design of the valve allows to adjust initial deflection of spring $\mathrm{x}_{\mathrm{z} 0}$, which gives the possibility to force the corresponding value of total pressures required to open the valve. This parameter determines a hydrostatic system response to the input value, and its choice is crucial for the proper operation of the system. The mathematical description of the valve was analyzed based on the literature $[5,15,16]$, in which the physical and mathematical models of pressure valves with indirect and direct action with one and/or two control pressures was described.

The condition of the valve opening and start-up flow is to filfilled the dependence (1): 


$$
p_{1} \cdot A_{z 1}+p_{3} \cdot A_{z 2}>k_{s} \cdot x_{z 0}
$$

where:

$\mathrm{A}_{\mathrm{z} 1}$ - cross-sectional area of the brake valve plunger,

$\mathrm{A}_{\mathrm{z} 2}$ - cross-sectional area of an additional element brake valve plunger,

$\mathrm{k}_{\mathrm{s}} \quad$ - stiffnes of the spring,

$\mathrm{x}_{\mathrm{z} 0} \quad$ - initial deflection of the spring.

The flow through the resulting orifice defines the equation (2). The displacement of the plunger within the valve is limited by the construction of the valve (3)

$$
\begin{gathered}
Q_{s z}=A_{s z} \cdot c_{s z} \cdot \sqrt{\frac{2 \cdot p_{1}}{\rho}}, \\
Q_{s z}=f\left(x_{z}\right),
\end{gathered}
$$

where:

$\mathrm{Q}_{\mathrm{sz}}$ - volume of the fluid flows through the valve,

$\mathrm{A}_{\mathrm{sz}}$ - cross-sectional area of the valve orifice,

$\mathrm{c}_{\mathrm{sz}}$ - discharge coefficient of the flow rate

$\rho \quad-$ fluid density

$\mathrm{x}_{\mathrm{z}}$ - deflection range of the spring during the movement of the plunger

The equation of motion of the plunger within the valve (4):

$$
m_{z t} \frac{d v_{z}}{d t}=p_{1(2)} \cdot A_{Z 1}+p_{3} \cdot A_{Z 2}-k_{1 S} \cdot\left(x_{Z 0}+x_{Z}\right)-f_{v z} \cdot v_{z},
$$

where:

$$
\begin{aligned}
& \mathrm{m}_{\mathrm{zt}} \quad \text { - mass of the plunger, } \\
& \mathrm{v}_{\mathrm{z}} \quad \text { - velocity of the plunger within the valve, } \\
& \mathrm{f}_{\mathrm{z}} \quad \text { - hyper viscous drag coefficient within the valve, }
\end{aligned}
$$

Based on measurements of the actual geometry of the valve and an analysis of its assembly drawing, which has been given by the manufacturer the company „Ponar Wadowice” a physical and mathematical model of such a valve has been created. Its description has been brought to the state variables and solved by numerical methods using computer software Lazarus. Block model used in the description was presented below (Fig. 4).

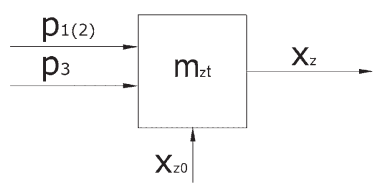

Fig. 4. The block model of the counterbalance valve

The simulation program with a simple interface which allows to observe the response of the valve to change of operating conditions and settings has been developed.

\section{The simulation tests valve}

The scope of research includes:

- changing the counterbalance valve setting with a constant flow,
- changing the counterbalance valve setting with a variable flow,

- control of opening the valve with a single pressure $p_{1}$,

- control opening the valve with two pressure $\mathrm{p}_{1}$ and $\mathrm{p}_{3}$

Oil is directed onto the surface of $\mathrm{A}_{\mathrm{zl}}$ (Fig. 1.2), which, in the absence of flow through the valve, increases the pressure $p_{1}$ to a value required to overcome the force of spring initial deflection. With the increase of the control pressure $p_{3}$ the gap expands in the valve and the pressure $p_{1}$ decreases to a point in which the valve is fully open. Further increase of pressure $p_{3}$ does not affect the movement of the valve piston, which abuts the stopper ring. Characteristics of pressure valve (Fig. 5) correspond to the theoretical assumptions, which appear in the literature [2]. Displacement of the piston $\mathrm{x}_{\mathrm{z}}$, at a given adjustment and a constant input function by the flow, presented in Fig. 6.

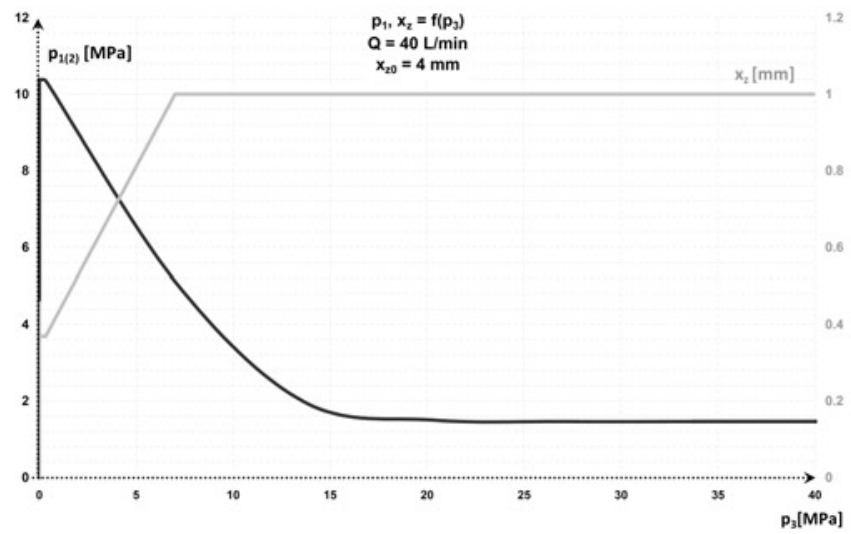

Fig. 5. Static characteristic and displacement of plunger inside the valve $x$ with constant deflection of the spring $x_{z 0}$
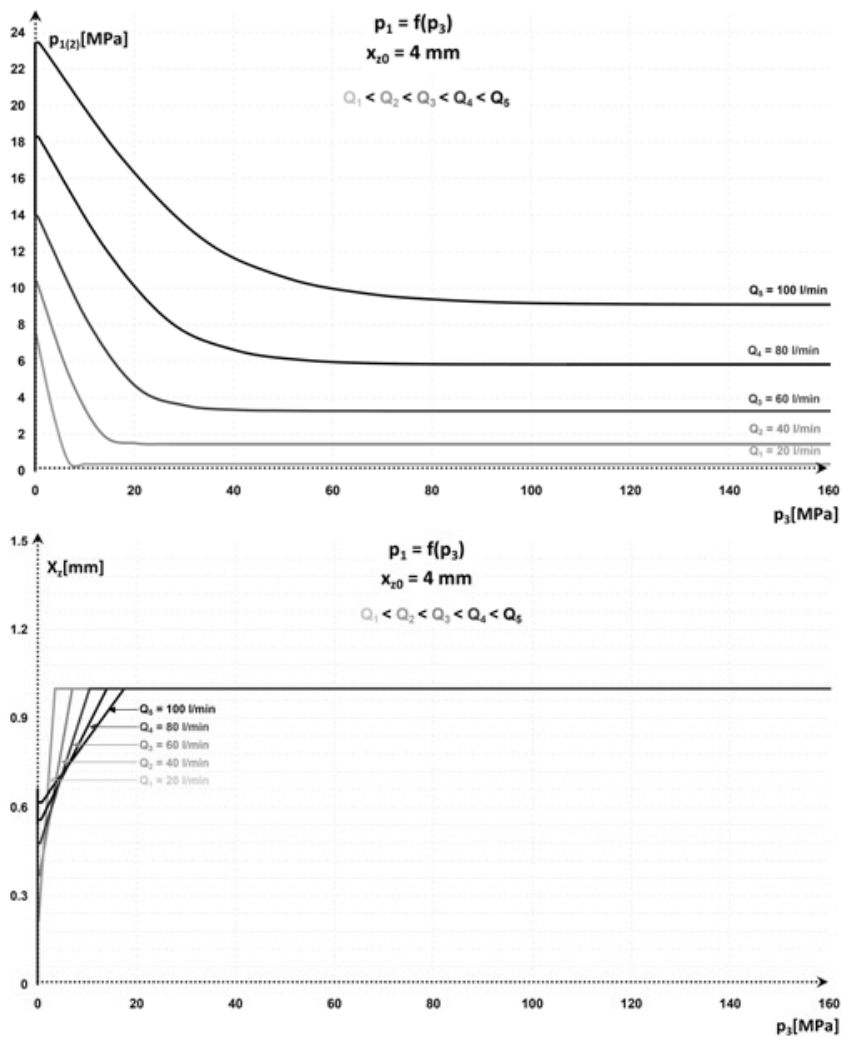

Fig. 6. Braking valve static characteristics and displacement plunger inside the valve $x_{z}$ for different values of flow with constant deflection of the spring $x_{z 0}$

To investigate the behavior of the valve at its various settings simulation tests at a constant flow rate have been carried out. The 


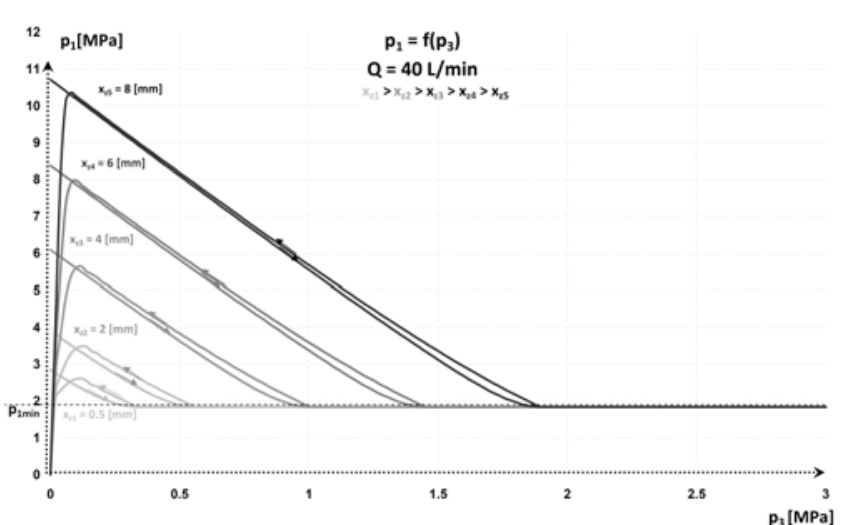

Fig. 7. The static characteristics of the braking valve for the specified flow at different deflection of the springs $x_{z 0}$

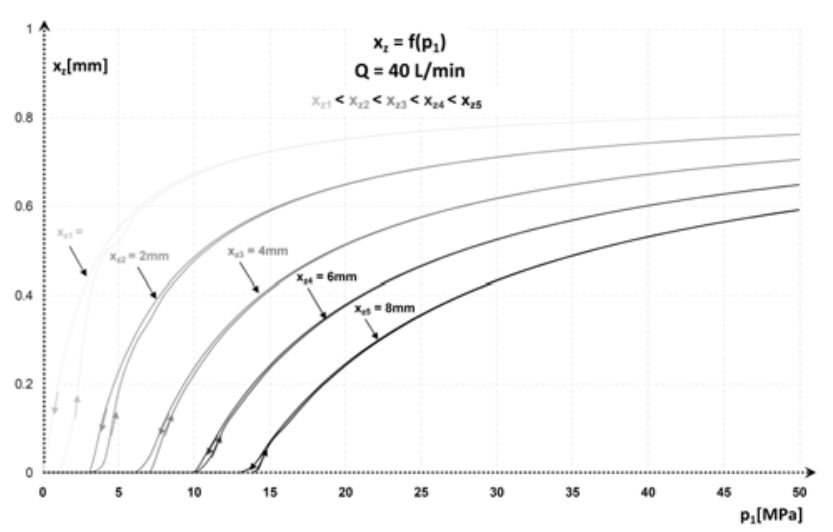

Fig. 8. Characteristics of displacement plunger inside the valve at different deflection of the spring $x_{z 0}$. Initial phase of opening the valve
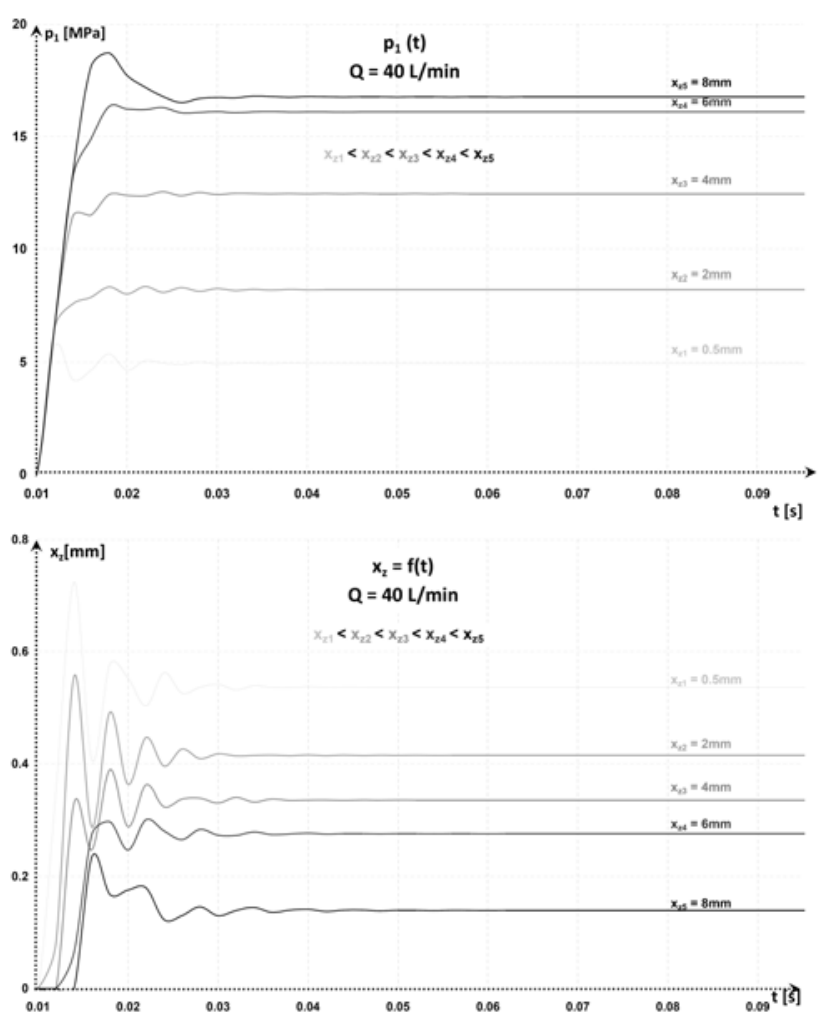

Fig. 9. Control pressures $p_{1}$ and displacements of the plunger inside the valve $x_{z}$ characteristics at different deflection of the spring $x_{z 0}$ counterbalance valve characteristics shown in Fig. 7. Through increase or decrease the pressure $p_{3}$ has been checked hysteresis effect, that is dependence of the current state of the system to the state in the preceding moments.

The sum of control pressures $p_{1}$ and $p_{3}$, needed to open the valve, varies with the change in the valve setting $\mathrm{x}_{\mathrm{z} 0}$. The flow through the valve at a smaller initial deflection of the spring occurs at low pressure $\mathrm{p}_{3}$ and low increasing of its is needed to fully open the valve. The valve is then very sensitive and works well at low loads, where precision counts. The opposite situation occurs when the valve setting is large and need a greater control signal. We achieve then high pressure $\mathrm{p}_{1}$ and it is needed in addition sufficiently large $\mathrm{p}_{3}$. Hysteresis occurs in the test valve, but it decreases with the increase in the spring stiffness and initial deflection of spring.

To accurately trace the plunger displacement inside the valve, simulation tests of the valve, forced only by pressure $p_{1}$ with absence of $\mathrm{p}_{3}$, has been done. Accordingly, by slowly increasing and decreasing the input signal $\mathrm{p}_{1}$, the appearance of hysteresis verified that occurs in the initial phase of opening of the valve, as shown in the enlarged view in Fig. 8. A further increase of pressure $p_{1}$ results an increase in movement of the plunger inside the valve, to the fully opened position, that is, the back of the plunger of the thrust ring.

To pay more attention to the dynamics of the valve and to show its reaction to the linear forcing the simulation tests have been done. The input signal flow was directed to a circuit coupled to the channel 1. Sample diagrams of pressure and plunger movement inside the valve for different initial settings of the spring show in Fig. 9. The higher initial setting of the valve, the bigger pressure $\mathrm{p}_{1}$ and the noticeable jump of this pressure appear after the valve is opened and the displacement of the plunger is smoother, without any vibrations. A lower setting results a higher susceptibility of the piston to vibrations during the opening. However, the pressure required to open the valve is reduced, without pressure peaks. The time of the valve opens is changing and it occurs more rapidly at low settings of the valve, when the valve is forced by the same input signal.

The control of the valve opening by means of one pressure $\mathrm{p} 1$ is encountered in practice very often. In this case, the valve acts as a pressure valve. Its operation will be similar to the braking valve with an internal control (Fig. 10), which is used to stop or hold a load back when the actuator does not need full power at the end of stroke. In the literature, it is sometimes called a over-centre (overcenter) valve $[3,6]$ or internally piloted counterbalance valve [7], as opposed to dual-pressure valve (internally/externally piloted counterbalance valve), which was the subject of this paper. This type of counterbalance valve retards continuosly, so it restists flow even after work contact stops the actuator. Power supply can be reduced and it allows to reduce pressure in the system and, in case of emergency, its stop and re-start occurs smoothly without shock and overload. However, the disadvantage of this valve is necessity to adjust the valve at each change of load.

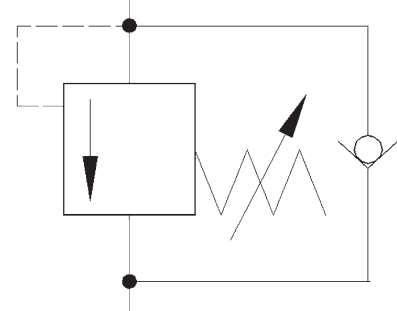

Fig. 10. The braking valve type counterbalance with internal pilot control - a graphic symbol 


\section{Evaluation of the impact of setting the braking valve on the behavior of the hydraulic system}

Based on experimental studies of the valve on the test stand the behavior of a system with counterbalance valves in various operating conditions of hydrostatic system was examined. Below there are examples of diagrams at the wrong settings of valves in the least favorable cycle, the so-called emergency. It means that, when the passage is in an active load it is switched off (approximately $12^{\text {th }}$ second of movement) and then re-powered (approximately $18^{\text {th }}$ second of movement) (Fig. 11 and Fig. 12). Unfortunately, in the case of mismatched settings of the valve, system vibrates, and the pressure reaches large and useless value.

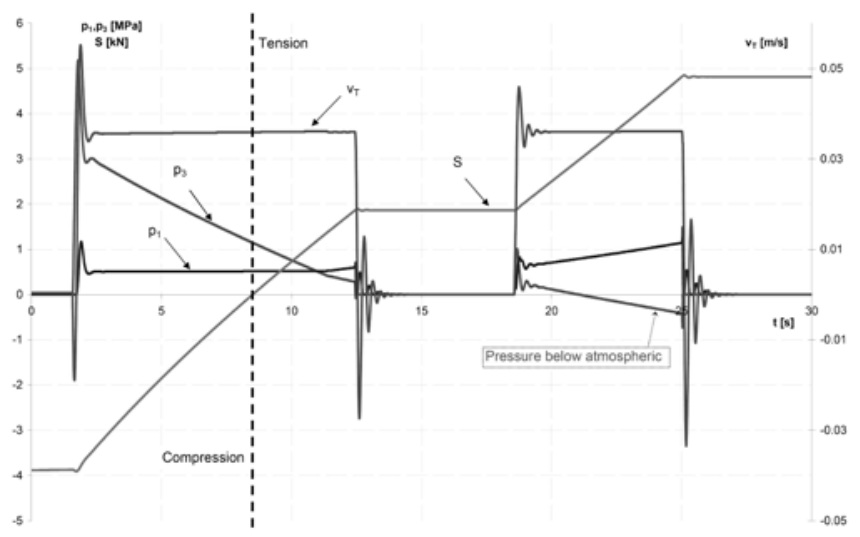

Fig. 11. The piston speed $v_{7}$, control pressures of the valve $p_{1}$ and $p_{3}$, force acting on the piston rod $S$ during the emergency cycle with too low stiffness of the spring in the counterbalance valve

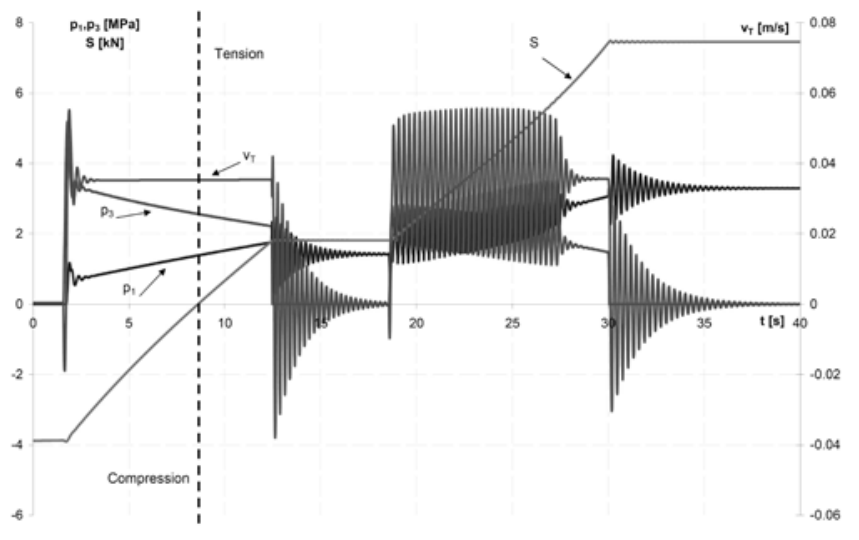

Fig. 12. The piston speed $v_{7}$, control pressures of the valve $p_{1}$ and $p_{3}$, force acting on the piston rod $S$ during the emergency cycle with too high stiffness of the spring in the counterbalance valve

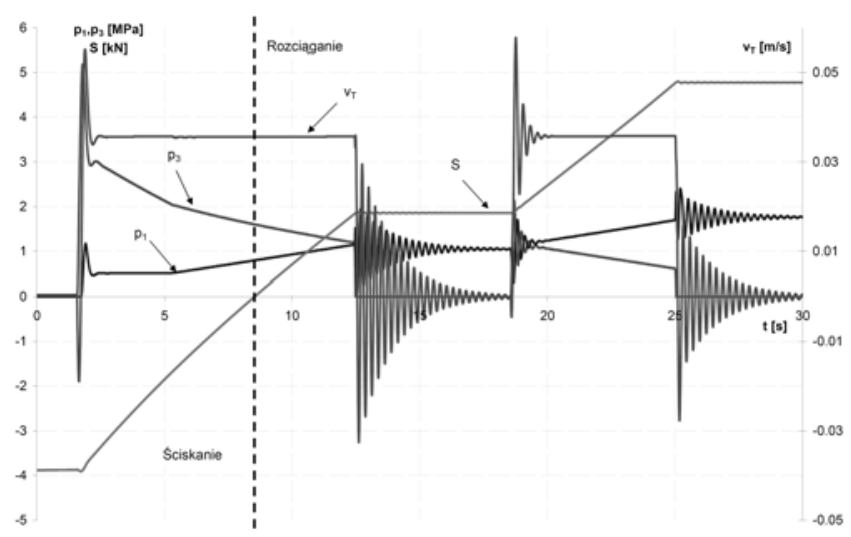

Fig. 13. The piston speed $v_{T}$, control pressures of the valve $p_{1}$ and $p_{3}$, force acting on the piston rod $S$ during the emergency cycle with correct stiffness of the spring in the counterbalance valve

While well-chosen setting valves (Fig. 13), the system moves smoothly both with a passive and active load, which gives a stable machine behavior and safety of its work. Thanks to the correct settings also provide low operating pressure, which has a positive effect on energy balance, that is a key element of today's research.

\section{Conclusions}

Choosing the setting of braking valves, all the conditions in which it will be working in the hydraulic system must be considered. Any change in the conditions requires different settings of the counterbalance valve. The above developed results show that the correct settings of the counterbalance valve provide smooth and stable behavior of the hydraulic system even in the case of lack of power supply. The paper discusses the simulation programs, both for the valve and for the hydrostatic system, so it is possible to analyze various parameters of any system. In addition, we have the ability to choose the right setting of the counterbalance valve, which will provide a fully controlled movement of the piston rod under all load conditions in any hydrostatic system with actuator.

\section{References}

1. Andersen Bo, R. Energy efficient load holding valve. The 11th Scandinavian International Conference on Fluid Power. Linkoping, 2009.

2. Bednarski S., Kontrolowany ruch siłownika z obciążeniem czynnym. Hydraulika i Pneumatyka 2012; 2: 10-14.

3. Cochran K. Cartridge valve and mianifold technologies - a components approach to improved energy efficiency. Energy efficient hydraulics and pneumatics conference. Rosemont, 2012.

4. Dabholkar R., Indulkar S., Overcenter valves are key to hydraulic control. Design World. www.designworldonline.com, 2012.

5. Dasgupta K., Watton J. Modeling and dynamics of a two-stage pressure rate controllable relief valve: A bondgraph approach. International Journal of Modelling and Simulation 2008; 28: 11-19, http://dx.doi.org/10.2316/Journal.205.2008.1.205-4336.

6. Hitchcox, A. The truth about problem valves. Hydraulics \& Pneumatics. The Penton Media Buildings. Cleveland, 2009.

7. Johnson J. L., Counterbalance Valve Circuits, Hydraulics \& Pneumatics, The Penton Media Building. Cleveland, 2009.

8. Karta katalogowa nr WK 498500 firmy Ponar-Wadowice.

9. Nordhammer P. A., Bak M. K., Hansen M. R. A method for reliable motion control of pressure compensated hydraulic actuation with counterbalance valve, 12th International Conference on Control. Automation and Systems 2012; 1: 759-763.

10. Nordhammer P. A., Bak M. K., Hansen M. R. Controlling the slewing motion of hydraulically actuated crane using sequential activation of counterbalance valve, 12th International Conference on Control. Automation and Systems 2012; 1: 773-778. 
11. Ritelli G. F. Energetic and dynamic impact of counterbalance valve in fluid power machines. Energy Conversion and Management 2013; 76: 701-711, http://dx.doi.org/10.1016/j.enconman.2013.08.021.

12. Stawiński, Ł. Badania symulacyjne układu hydrostatycznego z zaworem counterbalance. Międzynarodowa konferencja naukowo-techniczna: Napędy i Sterowanie Hydrauliczne i Pneumatyczne 2012; 1: 246-254.

13. Stawiński, Ł. Stanowisko laboratoryjne do badań układów hydrostatycznych ze zmiennym obciążeniem. Hydraulika i Pneumatyka 2014; 1 : $9-12$.

14. Stawiński, Ł. Układy hydrostatyczne do napędu siłowników przy zmiennym kierunku obciążanie tłoczyska. Hydraulika i Pneumatyka 2011; 1: 17-20.

15. Stryczek S. Napęd hydrostatyczny - elementy. WNT, Warszawa 1998.

16. Tomczyk J. Modele dynamiczne elementów i układów napędów hydrostatycznych WNT, Warszawa 1999.

17. Zhao L., Xinhui L., Tongjian W., Influence of counterbalance valve parameters on stability of the crane lifting system, International Conference on Mechatronics and Automation. Xi'an, 2010; 1: 1010-1014.

Łukasz STAWIŃSKI

Faculty of Mechanical Engineering

Lodz University of Technology

Departament of Vehicles and Fundamentals of Machine Design

ul. Żeromskiego 116, 90-924 Łódź, Poland

E-mail: lukasz.stawinski@p.lodz.pl 